\title{
Constructed wetland for slaughterhouse wastewater treatment
}

\author{
K. Keerthana and R. Thivyatharsan*
}

Department of Agricultural Engineering, Faculty of Agriculture, Eastern University, Sri Lanka

\begin{abstract}
Water quality has become a burning issue as best quality water is needed for daily lives. The slaughterhouses functioning at Batticaloa district generate huge amount of effluent and discharge to surrounding environment without proper treatment. It pollutes the surface water and soil as well. Discharging slaughterhouse wastewater without treatment contributes to greatly degrading the aquatic environment as well as human heal th issues. Therefore, there is a need to treat slaughterhouse wastewater before discharging into the water bodies and soil to avoid environmental pollution and human health effects. The objectives of the study were to design, construct and evaluate the efficiency of constructed wetland for the treatment of slaughterhouse wastewater with special reference to the parameters of chemical oxygen demand (COD), total dissolved solid (TDS), total suspended solid (TSS), nitrate, phosphate, biological oxygen demand (BOD) and $p H$ as well as to analyze the characteristics of slaughterhouse wastewater. The wetland was constructed with the layers of coir fiber, gravel and sand with the dimension of $1 m \times 1 m \times 0.3 m$. Cattail (Typha latifolia) plant was used as macrophytes. The results revealed that the removal of the above mentioned parameters increased with increasing retention time of wastewater in constructed wetland. The maximum removal efficiency of constructed wetland for the parameters of phosphate, $C O D, B O D_{5}$, nitrate, TDS and TSS nitrate and phosphate were $85.8 \%$, $77.5 \%, 93.3 \%, 68 \%, 71.3 \%$ and $88.7 \%$ respectively. It was concluded that the constructed wetland performed well for the treatment of slaughterhouse wastewater for the parameters of COD, TSS, TDS, $B O D_{5}$, nitrate and phosphate.
\end{abstract}

Keywords: Constructed wetland, slaughterhouse, wastewater

\section{Introduction}

Water is used for domestic, agriculture and industrial purposes. The slaughterhouse uses water for washing and cleaning operations of the meat, pipes, machines and floors. Thus, generates large quantity of water as wastewater with higher organic loading (Seif and Moursy, 2001). The treatment of water and wastewater has become crucial due to the continuous growth of world population and the pollution of freshwater because of not adequately treated wastewater discharged into environment, especially in developing countries (Bustillo-Lecompte and Mehrvar, 2015). Besides, the decreasing availability of freshwater has redirected the objectives in the area of wastewater treatment. Nevertheless, diverse techniques are
Corresponding author: thivyatharsan_r@yahoo.co.uk Received: 02.02.2018 adopted for water and wastewater treatment depending on the differences in geographic location, financial resources, living standards and life quality in different countries, as well as the characteristics of the wastewater effluents and pollutants (Daigger, 2009).

Slaughterhouses and meat processing plants (MPPs) are part of a large industry worldwide, where the composition of the wastewater depends on the diverse practices in the slaughtering process. Wastewaters from slaughterhouses and meat processing industries have been classified by Environmental Protection Agency (EPA) as one of the most harmful to the environment (Walter et al., 1974). Blood, 
one of the major dissolved pollutants in slaughterhouse wastewater has the highest COD of any effluent from slaughtering operations (Aniebo et al., 2009). The major characteristics of abattoir wastes are high organic strength, sufficient organic biological nutrients, adequate alkalinity, relatively high temperature $\left(20\right.$ to $\left.30^{\circ} \mathrm{C}\right)$ and free of toxic material (Aniebo et al., 2009). Consequently, slaughterhouse wastewater requires significant treatment for a safe and sustainable release to the environment.

Constructed wetlands systems are fully human-made wetlands for wastewater treatment that have been designed and constructed to utilize the natural processes involving wetland vegetation, soils and their associated microbial assemblages to assist in treating wastewater (Vymazal, 2005). Constructed wetlands are designed within a more controlled environment to take the advantages of the processes that occur in natural wetland. Constructed wetlands (CWs) are simple and low cost wastewater treatment systems that use natural processes utilizing shallow (usually less than $1 \mathrm{~m}$ deep) beds or channels, helophytes, substrate (soil, sand and gravels) and a variety of microorganisms to improve wastewater quality (EPA, 2008). As water flows through a wetland, it slows down and many of the suspended solids become trapped by vegetation and settled out. Other pollutants are transformed to less soluble forms taken up by plants or become inactive. Wetland plants also foster the necessary conditions for microorganisms to live there. Through a series of complex processes, these microorganisms also transform and remove pollutants from the water. And also, it is being used to treat petroleum refinery wastes, compost and landfill leachates, aquaculture discharges and pre-treated industrial wastewaters, such as those from pulp and paper mills, textile mills and seafood processing (EPA, 2008).
The major environmental problem associated with this slaughterhouse wastewater is the large amount of suspended solids and liquid waste as well as odor generation (Gauri, 2006). Effluent from slaughterhouses has also been recognized to contaminate both surface and groundwater because during abattoir processing blood, fat, manure, urine and meat tissues are lost to the wastewater streams (Bello and Oyedemi, 2009). Leaching into groundwater is a major part of the concern, especially due to the recalcitrant nature of some contaminants (Muhirwa et al., 2010). Discharging slaughterhouse wastewater without treatment contributes to greatly degrading the aquatic environment and pollution of irrigation water (Michael et al., 1988).

There are several slaughterhouses functioning at Batticaloa District and a huge amount of effluent is generated and discharged openly. It pollutes the surface water and soil as well as foul odor generation. Therefore, slaughterhouse wastewater should be treated before discharge into water bodies to avoid environmental pollution and human health effects.

This study was mainly focused on the use of constructed wetland for slaughterhouse wastewater treatment in Batticaloa District. The objective of the study were to design and construct wetland and to evaluate the efficiency of constructed wetland for the treatment of slaughterhouse wastewater treatment with special reference to the parameters of chemical oxygen demand (COD), total dissolved solid (TDS), total suspended solid (TSS), nitrate, phosphate, biological oxygen demand (BOD) and $\mathrm{pH}$ as well as to analyze the characteristics of slaughterhouse wastewater. 
Materials and Methods

\section{Materials}

\section{Wastewater:}

Actual slaughterhouse wastewater samples were taken from Eravur slaughterhouse using 20 liter containers and analyzed for the parameters such as COD, $\mathrm{pH}$, TDS, TSS, nitrate, phosphate and $\mathrm{BOD}_{5}$. Table 1 summarizes the main characteristics of the influent slaughterhouse wastewaters.

Table 1: Characteristics of actual slaughterhouse wastewater

\begin{tabular}{cccc}
\hline Parameter & Values $(\mathrm{mg} / \mathrm{l})$ & Mean $(\mathrm{mg} / \mathrm{l})$ & $\begin{array}{c}\text { CEA } \\
\text { Standards } \\
(\mathrm{mg} / \mathrm{l})\end{array}$ \\
\hline $\mathrm{pH}$ & $8.6-8.8$ & $8.7 \pm 0.1$ & $6.5-8.5$ \\
$\mathrm{TDS}(\mathrm{mg} / \mathrm{l})$ & $270.0-320.0$ & $296.7 \pm 25.2$ & 2100.0 \\
$\mathrm{TSS}(\mathrm{mg} / \mathrm{l})$ & $643.0-655.0$ & $649.3 \pm 6.0$ & 100.0 \\
BOD $(\mathrm{mg} / \mathrm{l})$ & $540.0-565.0$ & $551.7 \pm 12.6$ & 30.0 \\
COD $(\mathrm{mg} / \mathrm{l})$ & $1225.0-1155.0$ & $1193.0 \pm 35.5$ & 250.0 \\
Nitrate $(\mathrm{mg} / \mathrm{l})$ & $30.0-35.0$ & $32.3 \pm 2.5$ & 10.0 \\
Phosphate $(\mathrm{mg} / \mathrm{l})$ & $15.0-18.0$ & $16.8 \pm 1.6$ & 5.0 \\
\hline
\end{tabular}

Values are means of three replicates \pm standard deviation of replicate determination.

\section{Constructed wetland:}

The constructed wetland was constructed by using coir fiber, medium sized gravel and fine sand as wetland sediments and Catail plant (Typha latifolia) was using as macrophytes.

\section{Methods}

\section{Construction of wetland}

The wetland was constructed with dimension of $1 \mathrm{~m} \times 1 \mathrm{~m} \times 0.3 \mathrm{~m}$. Coir fiber was chopped and used for making bottom layer of $10 \mathrm{~cm}$ height. Medium sized gravel was added to form a middle layer of $10 \mathrm{~cm}$ height and fine sand was used as upper layer of $10 \mathrm{~cm}$ height for the construction of bed. The healthy and young cattail (Typha latifolia) plants were selected and transplanted into the bed. The PVC pipe was used to make outlet at the bottom of the bed to collect the treated water.

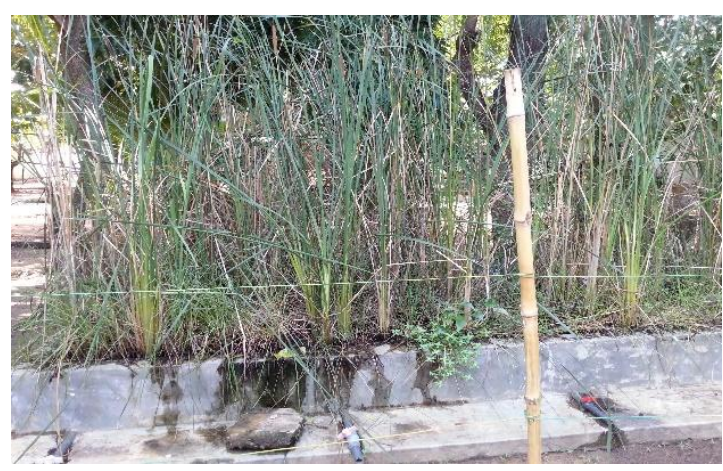

Fig. 1. Constructed wetland

At first, the wastewater was allowed to settle for 24 hours as preliminary treatment. And, the effluent from preliminary treatment was introduced into the constructed wetland through inlet pipe. The effluent from constructed wetland was collected directly from the outlet at $3^{\text {rd }}, 6^{\text {th }}$ and $9^{\text {th }}$ day and analyzed for different water quality parameters mentioned above. All parameters were measured according to Standard Methods (APHA, 19th edition 1995). 


\section{Experimental Setup and Procedure}

The experiment was laid out in a complete randomized design (CRD). The experiment consist one treatment such as activated charcoal with three replicates. The data were statistically analyzed through SAS software (SAS version 9.1). Treatment means were compared using t-test at 5\% significant level.

\section{Experimental site}

The study was carried out at Department of Agricultural Engineering, Faculty of
Agriculture, Eastern University, Sri Lanka during the period of July 2017 to October 2017.

\section{Results and Discussion}

Performance of constructed wetland in treating slaughterhouse wastewater

The changes of concentration of physicochemical parameters of slaughterhouse wastewater with retention time is shown in the Table 2. The results revealed that the concentration of these parameters was reduced significantly with retention time.

Table 2: Changes of physico-chemical parameters of slaughterhouse wastewater

\begin{tabular}{lllll}
\hline \multirow{2}{*}{ Parameters } & \multicolumn{4}{c}{ Retention time (days) } \\
& Initial value & 3 & 6 & 9 \\
\hline $\mathrm{pH}$ & $8.7 \pm 0.3$ & $7.7 \pm 0.1$ & $7.3 \pm 0.1$ & $7.2 \pm 0.1$ \\
TDS $(\mathrm{mg} / \mathrm{l})$ & $296.7 \pm 25.2$ & $213.3 \pm 20.1$ & $153.3 \pm 12.1$ & $85.0 \pm 5.0$ \\
$\mathrm{TSS}(\mathrm{mg} / \mathrm{l})$ & $649.3 \pm 6.0$ & $354.3 \pm 9.5$ & $90.0 \pm 5.0$ & $73.3 \pm 2.9$ \\
$\mathrm{BOD}(\mathrm{mg} / \mathrm{l})$ & $551.7 \pm 12.6$ & $345.0 \pm 10.0$ & $119.3 \pm 9.0$ & $30.3 \pm 5.5$ \\
COD $(\mathrm{mg} / \mathrm{l})$ & $1193.0 \pm 35.5$ & $918.3 \pm 30.3$ & $558.3 \pm 16.0$ & $253.3 \pm 10.4$ \\
Nitrate $(\mathrm{mg} / \mathrm{l})$ & $32.3 \pm 2.5$ & $25.3 \pm 1.5$ & $17.3 \pm 1.5$ & $10.3 \pm 1.5$ \\
Phosphate $(\mathrm{mg} / \mathrm{l})$ & $16.8 \pm 1.6$ & $12.0 \pm 1.3$ & $5.5 \pm 1.8$ & $2.4 \pm 0.6$ \\
\hline
\end{tabular}

Values are means of three replicates \pm standard deviation of replicate determination.

\section{Phosphate}

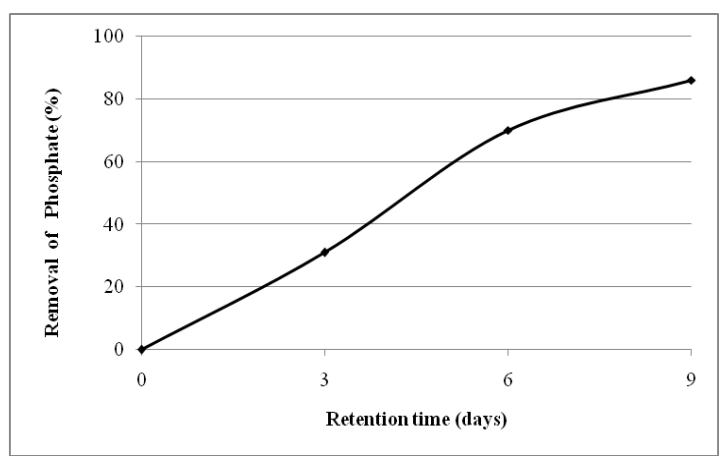

Fig. 2. Removal of phosphate with retention time

The phosphate removal in constructed wetland with retention time is shown in figure 2. It was found that the removal of phosphate increased with increasing retention time. The deposited sediments and macropytes present in wetland did major role in phosphate removal. DeBusk
(1999) and Fisher and Acreman (2004) reported that the retention time is significant in determining sedimentation rates, increasing contact time between nutrient load and wetland sediment and vegetation will increase the phosphate removal. Picard et al., (2005) reported that the plant present in wetland help in phosphate cycling and microbial processes, which are major processes involved in nutrient removal. It was observed that the removal of phosphate was higher in earlier days (up to $6^{\text {th }}$ day) and lesser later on because the sediments in the wetland became saturated with phosphate (Figure 2). Fink and Mitsch (2004) reported that the phosphorus removal (\%) decreased with time because sediment and litter in the wetland become saturated with phosphorus. 
The maximum removal (\%) of phosphate in constructed wetland was achieved to $85.8 \%$ at $9^{\text {th }}$ day. The phosphate in effluent from constructed wetland met the Central Environmental Authority (CEA) standards of maximum permissible limit (5 mg/l) permitted to safe discharge of industrial wastewater into inland water bodies.

\section{Biological Oxygen Demand (BOD)}

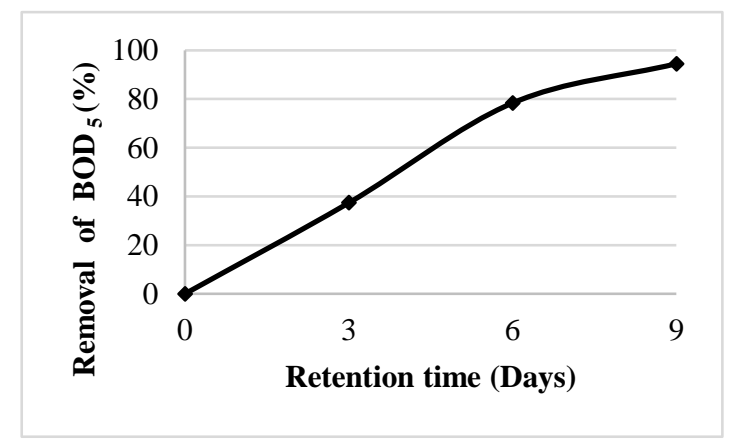

\section{Fig. 3. Removal of $\mathrm{BOD}_{5}$ with retention} time

It was found that the removal of $\mathrm{BOD}_{5}$ increased with increasing retention time, is shown in figure 3. Akratos et al., (2008) and Sindilariu et al., (2009) reported that higher retention time of wastewater in constructed wetlands was the most important positive factor in BOD removal efficiency. The results show that the constructed wetland removed $93.29 \%$ of $\mathrm{BOD}_{5}$ at 9 th day. The biological degradation and sedimentation were the major processes to remove $\mathrm{BOD}_{5}$ in constructed wetland. The abatement process of $\mathrm{BOD}_{5}$ is mainly carried out by bacterial activity (aerobic and anaerobic) with greenhouse gases production and emission to the atmosphere (Mander et al., 2014 and Barbera et al., 2014) and by the sedimentation and filtration of particulate organic matter (Vymazal and Kropfelova, 2008).

The $\mathrm{BOD}_{5}$ of the effluent of constructed wetland met the CEA standards of maximum permissible limit (30mg/l) permitted to safe discharge of industrial wastewater into inland water bodies.

\section{Chemical Oxygen Demand (COD)}

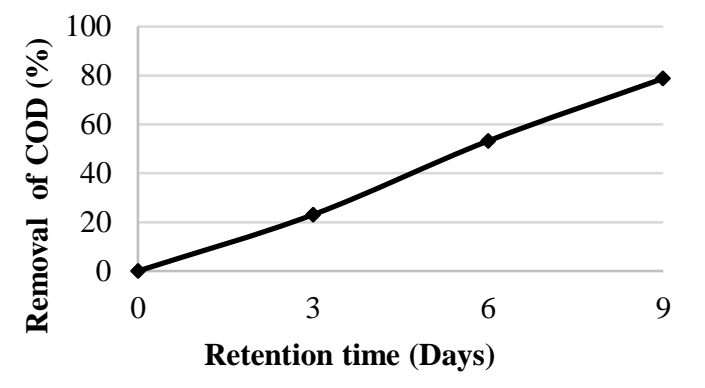

Fig. 4. Removal of COD with retention time

The removal of COD increased with increasing retention time as illustrated in figure 4. Constructed wetland was able to oxygenate the beds to a level that supports the aerobic degradation of the organic load of wastewater. In addition, the vegetation provided a substrate (roots, stems and leaves) upon which microorganisms can grow as they break down organic molecules.

The removal of COD in constructed wetland was achieved to $77.5 \%$ at $9^{\text {th }}$ day. The effluent COD of constructed wetland was lower than the maximum permissible limit $(250 \mathrm{mg} / \mathrm{l})$ of CEA standards permitted for safe discharge of industrial wastewater in to the inland water surface.

\section{Nitrate}

The initial nitrate concentration of slaughterhouse wastewater was $32.3 \pm 2.5$ $\mathrm{mg} / \mathrm{l}$ (Table 2). Constructed wetland reduced the nitrate significantly from the wastewater. Denitrification, adsorption and incorporation into cell mass were the key process for the reduction of nitrate in constructed wetland. The studies conducted by DeBusk (1999) and Al-Omari et al. (2003) proved this finding. DeBusk (1999) reported that nitrate removal in wetlands is usually very high. 


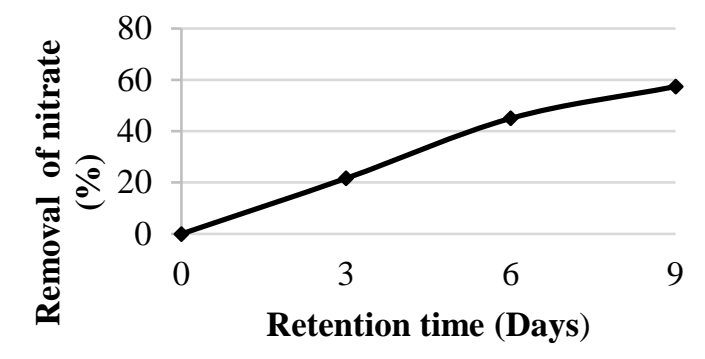

Fig. 5. Removal of nitrate with retention time

Nitrate removal increased with increasing retention time as shown in the figure 5 . Bastviken (2006) and Fink and Mitsch (2004) found that long retention time and accumulation of the organic material increase the rate of denitrification in wetland. These ultimately reduce the amount of nitrate from wastewater.

According to the graph (Figure 5) higher removal of nitrate was observed in initial period because of increased uptake of nitrogen by wetland plants and microflora as well as denitrification process. However, nitrogen removal was dropdown slightly after sixth day due to increased dissolved oxygen (DO) which is produced by passive aeration and photosynthesis of wetland plants. This DO enhanced nitrification rates. Vymazal and Brezinova (2015) reported that constructed wetland offers good requirements of oxygen which leads unfavourable conditions for the denitrification of $\mathrm{NO}_{3}$. Eastman et al., (2009) also stated high DO in wetlands causes the nitrification process through a decrease in ammonia levels and an increase of nitrates. Retention time was an important factor in determining the rate of nitrate removal. As per the results, nitrate removal increased with increasing retention time. It was due to an increase in thickness of biological membrane formed around the sediment which led to the direct emergence of an oxygen deficient area around the bed particles that helped to remove nitrates. Andersson et al., (2005) has also proven that the removal of nitrate in wetland depends on hydraulic retention time of the wetlands, oxygen concentration and organic matter content.
The removal of nitrate in constructed wetland was achieved to $68 \%$. The nitrate of effluent from constructed wetland was lower than the maximum permissible limit $(10 \mathrm{mg} / \mathrm{l})$ of CEA permitted for safe discharge of industrial wastewater into the inland water bodies.

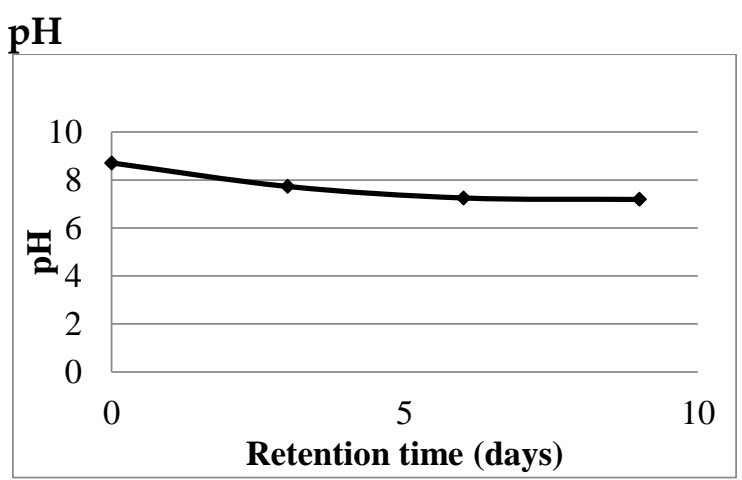

Fig. 6. changes of $\mathrm{pH}$ with retention time

The change of $\mathrm{pH}$ with retention time is illustrated in figure 6 . The results indicated that the $\mathrm{pH}$ reduced gradually with retention time. It was observed that the $\mathrm{pH}$ plummeted in earlier days and reached closer to neutral of 7.28 at ninth day. Mayes et al., (2009) reported that the aquatic macrophytes in wetlands mainly provided a substratum. Hence, that decomposing microorganisms raised free $\mathrm{CO}_{2}$ in water. The $\mathrm{CO}_{2}$ from the respiration of microorganisms in the constructed wetland might have helped in the decrease of $\mathrm{pH}$ at the outlet.

The value of $\mathrm{pH}$ in the effluent of constructed wetland met the CEA standards of maximum permissible limit (6.5-8.5) permitted to safe discharge of industrial wastewater into inland water bodies.

\section{Total Dissolved Solids (TDS)}

The quantity of TDS was considerably decreased along with the time in constructed wetland. It was clearly shown in the table 2. 


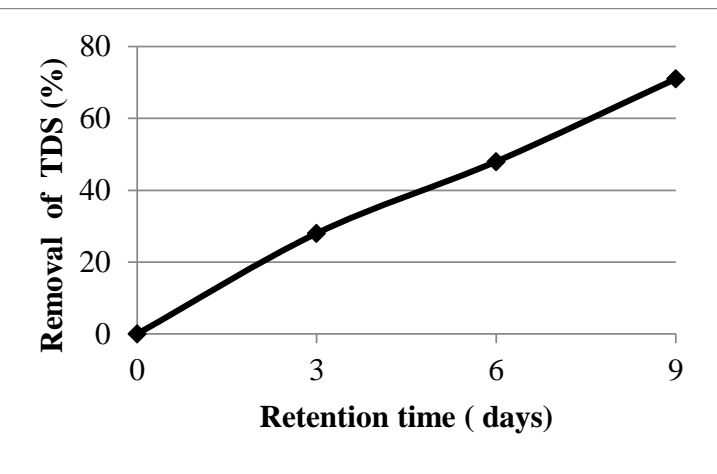

Fig. 7. Removal of TDS with retention time

The TDS removal was increased with increasing retention time as shown in figure 7. There are three main processes that remove TDS namely binding to soils, sedimentation and particulate matter, precipitation as insoluble salts and uptake by bacteria, algae and plants (Kadlec and Knight, 1996). A certain level of ions in water is really necessary for plant and they are biologically utilized or chemically reactive in wetland. This may be the reason for the rapid reduction of TDS in wetland. The removal of TDS was achieved to $71.34 \%$ at the end of the treatment. The TDS in the effluent of constructed wetland was lower than the maximum permissible limit $(2100 \mathrm{mg} / \mathrm{l})$ of CEA standards permitted for safe discharge of industrial wastewater in to inland water surface.

\section{Total Suspended Solids (TSS)}

It was observed that the TSS was reduced with retention time. The mean values of the effluent of constructed wetland were $354.3 \pm 9.5 \mathrm{mg} / 1$ at $3^{\text {rd }}$ day and $73.3 \pm 2.9$ $\mathrm{mg} / \mathrm{l}$ at $9^{\text {th }}$ day (Table 2). Thus, the wetland removed considerable amounts of suspended solids from the wastewater. Sedimentation, filtration, adsorption onto biofilm and flocculation/precipitation were the major processes for the reduction of TSS in wetland. Further, the surface area of plant stems trapped fine materials within its rough structure. According to Vymazal (1998) studies, the suspended solids are mainly removed by constructed wetland via physical processes such as sedimentation and filtration. Filtration occurs by the impaction of particles onto the roots and stems of the macrophytes or onto the soil/gravel particles in sediments.

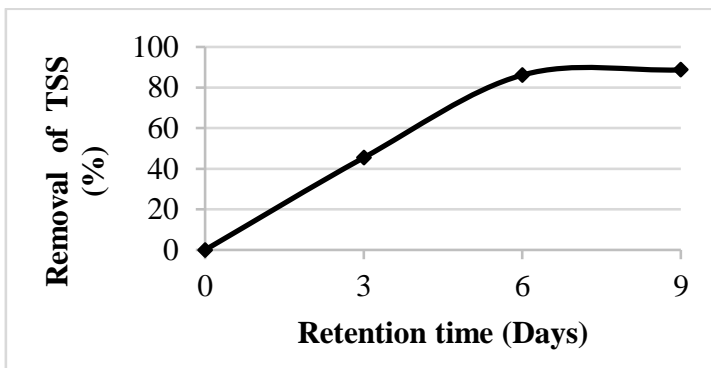

Fig.8. Removal of TSS with retention time The removal of TSS with retention time is graphically shown in figure 8 . According to this graph it was observed that suspended solids decreased with increasing the time of treatment. The higher removal of suspended solids indicated the effectiveness of constructed wetland. Constructed wetland removed around $88.7 \%$ of TSS from wastewater.

\section{Conclusion}

The results of the study revealed that the constructed wetland had an ability to treat slaughterhouse wastewater. It was clear from the results that there was a significant reduction in the concentration of above discussed parameters with retention time. The initial mean values of slaughterhouse wastewater during the study period were obtained as COD of $1193.0 \pm 35.5 \mathrm{mg} / 1$, TSS of $649.3 \pm 6.0 \mathrm{mg} / \mathrm{l}$, TDS of $296.7 \pm 25.2 \mathrm{mg} / \mathrm{l}$, $\mathrm{BOD}_{5}$ of $551.7 \pm 12.6 \mathrm{mg} / 1$, nitrate of $32.3 \pm 2.5$ $\mathrm{mg} / \mathrm{l}, \mathrm{pH}$ of $8.7 \pm 0.3$ and phosphate of $16.8 \pm 1.6 \mathrm{mg} / \mathrm{l}$. The concentration of Nitrate, phosphate, $\mathrm{BOD}_{5}, \mathrm{COD}, \mathrm{TSS}$ and $\mathrm{pH}$ in slaughterhouse wastewater were higher as compared to Central Environmental Authority permissible limits for safe discharge of industrial wastewater into inland water bodies.

Therefore, this study showed that there was significant reduction in the concentration of parameters with the treatments of constructed wetland. Maximum removal efficiency of COD, TSS, TDS, $\mathrm{BOD}_{5}$, nitrate and phosphate with constructed wetland were $77.5 \%, 88.7 \%, 71.3 \%, 93.3 \%, 68 \%$ and $85.8 \%$ respectively. The nitrate, phosphate, 
COD, TDS, $\mathrm{pH}$, TDS and $\mathrm{BOD}_{5}$ of effluent treated with constructed wetland had lower than that of maximum permissible limit of CEA standards for the safe discharge of industrial wastewater into inland water bodies. Finally, it could be concluded that the constructed wetland ensure a more stable removal of pollutants from slaughterhouse wastewaters.

\section{References}

Akratos, C. S., Papaspyros, J. N. E. and Tsihrintzis, V. A. (2008). An artificial neural network model and design equations for BOD and COD removal prediction in horizontal subsurface flow constructed wetlands. Chemical Engineering Journal, 143: 96-110.

Al-Omari, Abbas and Fayyad, Manar. (2003). Treatment of domestic wastewater by subsurface flow constructed wetlands in Jordan. Desalination, 155: 27-39.

Andersson, J. L., Bastviken, S. K. and Tonderski, K. S. (2005). Free water surface wetlands for wastewater treatment in Sweden: nitrogen and phosphorus removal. Water Science and Technology, 51(9): 31- 46.

Aniebo, A. O., Wekhe, S. N. and Okoli, I. C. (2009). Abattoir blood waste generation in river state and its environmental implications in the niger delta. Toxicol. Environmantal Chemistry, 91:619-625.

Barbera, A.C., Borin, M., Cirelli, G.L., Toscano, A. and Maucieri, C. (2014). Comparison of carbon balance in Mediterranean pilot constructed wetlands vegetated with different $\mathrm{C} 4$ plant species. Environmental Science and Pollution Research International, 22: 2372-2383.

Bastviken, S. (2006). Nitrogen removal in treatment wetlands -Factors influencing spatial and temporal variations. Dissertation No 1041. Linköping University, Sweden.
Bello, Y. O. and Oyedemi, D. T. A. (2009). The impact of abattoir activities and management in residential neighbourhoods: A case study of Ogbomoso, Nigeria. Journal of Social Sciences, 19 (2): 121-127.

Bustillo-Lecompte, C.F. and Mehrvar, M. (2015). Slaughterhouse wastewater characteristics, treatment, and management in the meat processing industry: A review on trends and advances. Journal of Environmental Management, 161: 287-302.

Daigger, Glen. (2009). Evolving urban water and residuals management paradigms: Water reclamation and reuse, decentralization, and resource recovery. Water Environment Research: a Research Publication of the Water Environment Federation, 81: 809-23.

DeBusk, W. F. (1999). Wastewater treatment wetlands: Applications and treatment efficiency. A fact sheet of the Soil and Water Science Department, Florida Cooperative Extension Service, Institute of Food and Agricultural Sciences, University of Florida.

Eastman, J., Gagnon, V.,Sundberg, C., Chazarenc, F., Burr, M.,Brisson, J., Camper, A., Stein, O. (2009). Microbial processes influencing performance of treatment wetlands: A Review. Ecological Engineering, 35: 987-1004.

EPA, U. S. (2008). EPA's Report on the Environment (Roe) (2008 Final Report). U.S. Environmental Protection Agency, Washington, D.C., EPA/600/R-07/045F (NTISPB2008-112484).

Fink, D.F. and Mitsch, W.A. (2004). Seasonal and storm event nutrient removal by a created wetland in an agricultural watershed. Ecological Engineering, 23(5): 313325 . 
Fisher, J. and Acreman, M.C. (2004). Wetland nutrient removal: a review of the evidence. Hydrology and Earth Systems Science, 8(4): 673-685.

Gauri, S. M. (2006). Treatment of wastewater from abattoirs before land application: a review. Bioresource Technology, 97 (9): 1119-1135.

Kadlec, R. H. and Knight, R. L. (1996). Treatment wetlands. New York: Lewis Publishers, CRC.

Mander, Ü., Tournebize, J., Kasak, K., Mitsch, W.J. (2014). Climate regulation by free water surface constructed wetlands for wastewater treatment and created riverine wetlands. Ecological Engineering, 72: 103115.

Mayes, W. M., Batty, L. C., Younger, P. L., Jarvis, A. P., Koiv, M., Vohlc, C. and Mander, U. (2009). Wetland treatment at extremes of $\mathrm{pH}$ : A review. Science of the Total Environment, 407(3): 944-957.

Michael, N. N., Terry, W. S. and Graig, L. B. (1988). Anaerobic contact pre-treatment of slaughterhouse wastewater. Proceeding of the Industrial Waste Conference, 42: 647.

Muhirwa, D., Nhapi, I., Wali, U., Banadda, N., Kashaigili, J. and Kimwaga, R. (2010). Characterization of wastewater from an abattoir in Rwanda and the impact on downstream water quality. International Journal of Ecology \& Development, 16:30- 46.

Picard, C.R., Fraser, L.H. and Steer, D. (2005). The interacting effects of temperature and plant community type on nutrient removal in wetland microcosms. Bioresource Technology, 96(9): 1039 - 1047.

Seif, H. and Moursy, A. (2001). Treatment of slaughterhouse wastes. Sixth International Water Technology Conference, 269-275.

Sindilariu, P.D., Brinker, A. and Reiter, R. (2009). Factors influencing the efficiency of constructed wetlands used for the treatment of intensive trout farm effluent. Ecological Engineering, 35(5): 711722.

Vymazal, J. (1998). Types of constructed wetlands for wastewater treatment. In: A Paper presented at the Sixth International Conference on Wetland Systems for Water Pollution Control, Aguas de Sao Pedro, Brazil.

Vymazal, J. (2005). Constructed wetlands for waste water treatment. Ecological Engineering, 2: 472-478.

Vymazal, J. and Brezinova, T. (2015). The use of constructed wetlands for removal of pesticides from agricultural run-off and drainage: A review. Environment International, 75: 11-20.

Vymazal, 1. and kropfelova, 1. (2008). Waste water treatment in constructed wetland with horizontal subsurface flow, springer, Dordrecht.

Walter, R.H., Shermah, R.M. and Downing, D.L. (1974). Reduction in oxygen demand of abattoir effluent by Precipitation with metal. Journal of Agric Food Chemistry, 22: 1097-1099. 